\title{
Low-temperature Hydraulic Binders for Restoration Needs
}

\author{
Inta Barbane ${ }^{1}$, Inta Vitina ${ }^{2}$, Linda Krage ${ }^{3},{ }^{1-3}$ Riga Technical University
}

\begin{abstract}
The late $19^{\text {th }} /$ early $20^{\text {th }}$ century was a period of active usage of low-temperature hydraulic binders, e.g., Roman cement, for the construction of buildings. Dolomitic Roman cement was characteristic of Latvia in contrast to the rest of Europe, where calcitic Roman cement was applied. The research has been conducted with the aim to synthesize a binder from local clay and dolomite compatible with historical dolomitic Roman cement. The results of chemical and XRD phase analyses have approved that Devonian as well as Quaternary clay mixed with dolomite can form a binder that closely conforms with historical ones. The obtained compositions can be considered perspective for restoration needs.
\end{abstract}

Keywords: hydraulic components, low-temperature binder, restoration, Roman cement

\section{INTRODUCTION}

A great part of the most famous cultural heritage of Latvia Art-Nouveau style buildings - has reached its centenary. Now it is time to start restoration of these buildings. Therefore, careful research of the historic building material is an obligate prerequisite to provide qualitative restoration and durability of one of the most valuable identity signs of Riga.

The late $19^{\text {th }}$ and early $20^{\text {th }}$ centuries were periods, when the dominance of European Historicism and Art Nouveau style in architecture coexisted with the dominance of hydralic lowtemperature binders in building construction and decoration. Low-temperature natural cement - Roman cement - was a hydraulic binder produced by firing marl (mineral composed of $60-75 \%$ of calcite or dolomite and $25-40 \%$ of clay) below its sintering temperature $\left(800-1200{ }^{\circ} \mathrm{C}\right)$ and by fine grinding. This binder was characterized by fast setting (usually 7-20 min), beautiful texture, warm brown colour and good durability [1].

In Latvia, in contrast to other parts of Europe, dolomitic Roman cement was produced. However, since the middle of the $20^{\text {th }}$ century its production has been stopped and earlier craft techniques and production technologies have been forgotten [2].

Nowadays, there is the necessity for compatible material for restoration needs. The lack of original historic binders has led to misunderstandings and poor quality restoration work. For this reason, extensive research has been conducted in Central Europe to bring back the historic material and technology [3].

In recent years, there has been increasing interest in the $19^{\text {th }} / 20^{\text {th }}$ century architecture and its restoration. Several projects [3] have been carried out in Central Europe to examine historically used binders and create a strategy for their restoration. Many attempts have been undertaken to find a technology for the manufacturing of these historic binders and, what is more important, of new ones that would be compatible with historic ones and, therefore, suitable for restoration purposes. Since 2003, such international projects as ROCEM (2003-2006) and ROCARE (2009-2012) have been carried out (in cooperation with scientists from the United Kingdom, Poland, Austria and other countries) with an objective of conducting systematic studies aimed at promoting Roman cement "rebirth", exploring its properties and improving technology in order to obtain the material suitable for restoration purposes. Within the framework of these projects, historic renders based on calcitic Roman cement have been extensively studied, as well as this historic material and the technology for conservation practice have been re-established (Fig. 1).

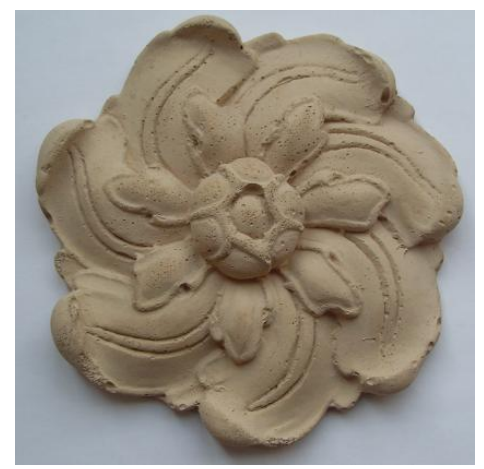

Fig. 1. Ornament made of experimentally synthesized calcitic Roman cement in the framework of the ROCEM project (2003-2006)

However, dolomitic Roman cement has not been included in these projects because dolomitic marl as a raw material is not obtained in the main part of Europe. As it dominated in Latvia's architecture in the 19th/ 20th centuries and it has specific properties different from calcitic Roman cement, local scientists have devoted attention to it in previous studies [2,4,5].

Production of dolomitic Roman cement in the territory of Latvia started in 1865 , when a hydraulic binder was obtained by firing dolomitic marl (domerite) at $800-900{ }^{\circ} \mathrm{C}$ and by fine milling [2]. Due to a relatively high amount of active $\mathrm{CaO}+\mathrm{MgO}$, it required storage in a moist environment for a few months before usage. Dolomite with clay content exceeding $15 \%$ was used for the production of the so-called "Riga cement". Setting time of dolomitic Roman cement is longer than that of calcitic Roman cement (it usually sets in $30 \mathrm{~min}$ or up to 3h) [6]. Production of dolomitic Roman cement was stopped after World War II. Industrial production of dolomitic Roman cement from local marlstone is not possible anymore, because its deposits are not sufficiently available. However, in Latvia there are rich resources of mineral raw materials (dolomite, clay, sand, limestone etc.) [5]. 
Therefore, for the restoration purposes a new method has been worked out in order to obtain composition from an artificially made mixture of dolomite and clay similar to natural marlstone that could be later fired and, as a result, a binder could be obtained, similar to historical Roman cement made of natural dolomitic marl.

\section{METHODS OF RESEARCH}

For the synthesis of hydraulic low-temperature binder, two types of clay - Quaternary (Spartaks deposit) and Devonian (Liepa deposit) clay with carbonate content $23 \%$ and $3 \%$, respectively - mixed with dolomite powder were used.

Clay content (13-30\%) in mixtures closely conforms with chemical composition of dolomitic marl, which was original raw material for Roman cement [6].

Both the chemical and phase compositions of the raw materials were analysed. The results of the full chemical analysis, XRD and DTA, have been reported previously [7].

Specimens were prepared by weighing the requisite amount of raw materials - clay and dolomite - and by homogenizing the mixture in the dry state.

Plate samples were shaped by semidry pressing, dried and fired in the temperature range of $750-950^{\circ} \mathrm{C}$ in $50^{\circ} \mathrm{C}$ steps with the holding time at each temperature for 2 hours. Natural dolomitic marl (Dzukste, Latvia) was treated under the same conditions.

Development of phases in the obtained material depending on the production temperature was also investigated. Changes in phase composition during hydration processes within 28 days were observed by XRD. For this reason, fired samples were grinded and water was added in order to obtain binder consistency. During the hydration process, the samples were kept in a moist environment. Chemical and phase compositions were compared in fired natural dolomitic marl and synthesized mixtures, as well as in different Roman cement samples.

Chemical and mineralogical compositions of raw materials and synthesized binders were established by:

1) a full chemical analysis (carried out according to EN 196-2 and A Laboratory Manual for Architectural Conservators (Teutonico, J.M., 1988));

2) XRD (Rigaku Ultima + with $\mathrm{CuK} \alpha$ );

3) DTA/TG (SETARAM SETSYS Evolution - 1750).

\section{RESULTS AND DISCUSSION}

The results of XRD analysis show that crystalline phases of the synthesized compositions after firing are equal to crystalline phases in dolomitic marl fired at the same temperature. The main crystalline phases are quartz $\left(\mathrm{SiO}_{2}\right)$, calcium oxide $(\mathrm{CaO})$, dicalcium silicate $\left(2 \mathrm{CaO} \cdot \mathrm{SiO}_{2}\right)$, magnesium oxide $(\mathrm{MgO})$ and tricalcium aluminate (3 $\left.\mathrm{CaO} \cdot \mathrm{Al}_{2} \mathrm{O}_{3}\right)$ (Fig. 2). Gehlenite $\left(2 \mathrm{CaO} \cdot \mathrm{Al}_{2} \mathrm{O}_{3} \cdot \mathrm{SiO}_{2}\right)$ appears at temperatures higher than $850{ }^{\circ} \mathrm{C}$. At temperatures lower than $850{ }^{\circ} \mathrm{C}$ undissociated dolomite $\left(\mathrm{MgCO}_{3} \cdot \mathrm{CaCO}_{3}\right)$ and calcite $\left(\mathrm{CaCO}_{3}\right)$ have also been detected [7].

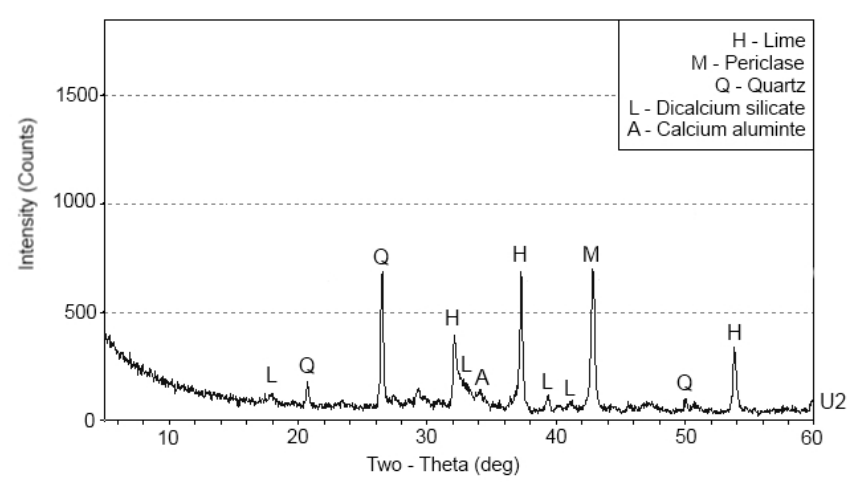

Fig. 2.XRD of synthesized mixture U2 (24\% of Quaternary clay and $76 \%$ of dolomite) after firing at $850{ }^{\circ} \mathrm{C}$

Comparing compositions with an equal dolomite-clay ratio (A2 and U2), the intensity of crystallization and crystalline phases in both compositions are similar. Composition A2 contains more quartz due to a high content of it in Devonian clay [8].

The formation of cement minerals - tricalcium aluminate and dicalcium silicate - is the base for development of hydraulic properties. Hydraulic hardening could not be achieved without formation of cement minerals. Tricalcium aluminate provides quick setting (characteristic of Roman cement), but dicalcium silicate - gradual growth of strength which is important for longevity of mortar [1]. In the synthesized mixtures they are detected after firing at temperatures higher than $800{ }^{\circ} \mathrm{C}$. When Devonian clay is used, crystallization of cement minerals appears already at $750{ }^{\circ} \mathrm{C}$.

The relative changes in the amount of crystalline phases were observed by measuring the characteristic peaks of each phase under equal conditions. Formation of two main cement minerals depending on the firing temperature is indicated in Fig. 3 and Fig. 4. The tendency is similar for synthesized composition $\mathrm{U} 2$ and natural dolomitic marl. Crystallization of $2 \mathrm{CaO} \cdot \mathrm{SiO}_{2}$ and $3 \mathrm{CaO} \cdot \mathrm{Al}_{2} \mathrm{O}_{3}$ begins at $800{ }^{\circ} \mathrm{C}$ and increases at higher temperatures. Crystallization of dicalcium silicate reaches maximum at $900{ }^{\circ} \mathrm{C}$. Composition A2 distinguishes itself by formation of $2 \mathrm{CaO} \cdot \mathrm{SiO}_{2}$ at lower temperatures and even increases of it.

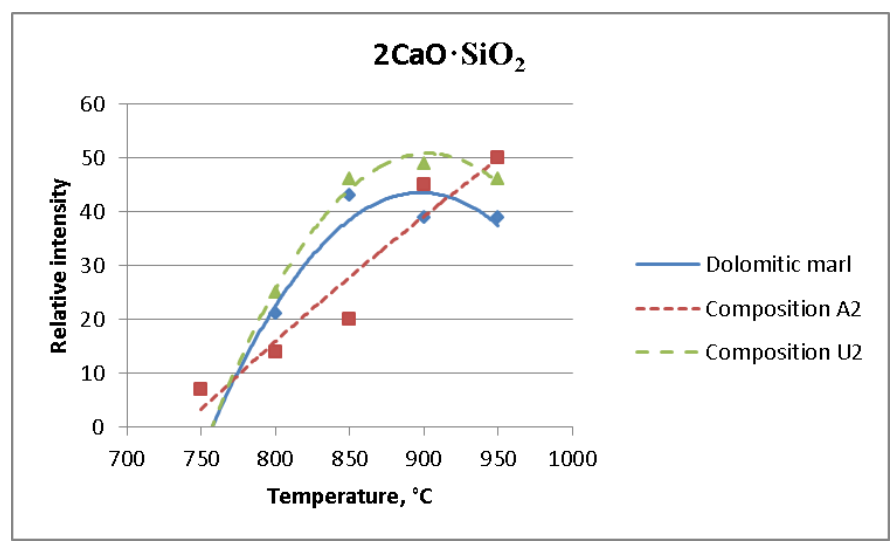

Fig. 3. The changes of the amount of dicalcium silicate crysatlline phase depending on the firing temperature 


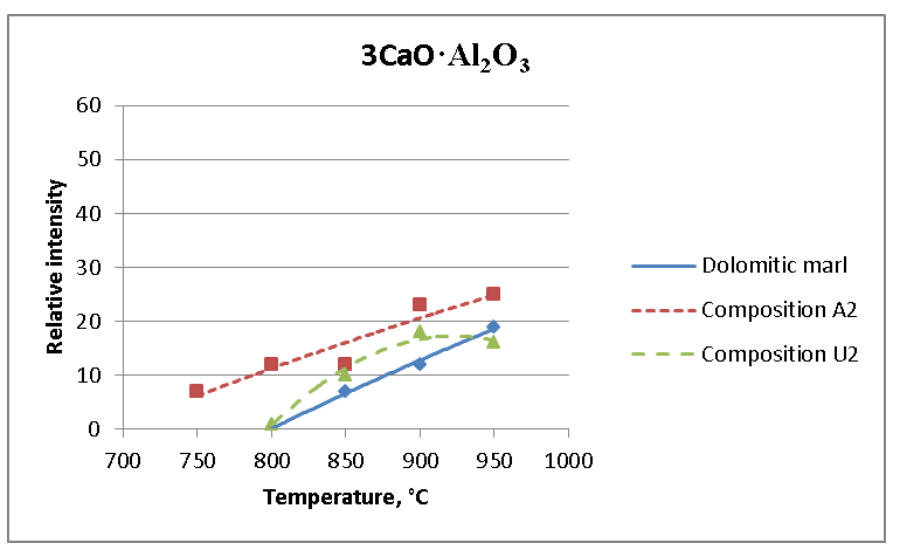

Fig. 4. The changes of the amount of tricalcium aluminate crysatlline phase depending on the firing temperature

Hydraulic components are particularly important when the binder is exposed to a moist environment. Several mistakes have been made when pure lime without hydraulic components has been used in restoration. It can lead to peeling of outer layers as it is shown Fig. 5.

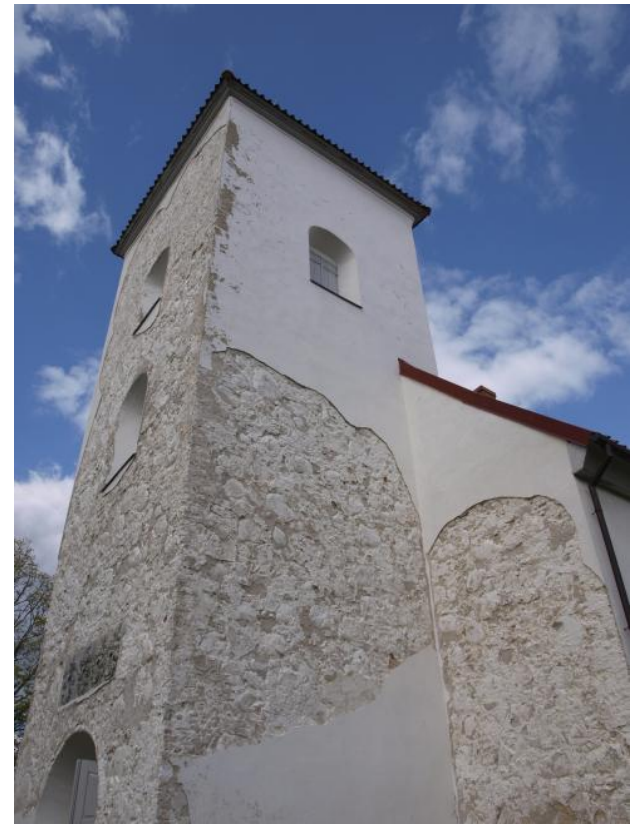

Fig. 5. Result of the usage of pure lime binder without hydraulic components in the restoration of Puze church, Latvia

Hydraulic properties of restoration materials are not important only for the restoration of buildings, where natural cement was used for their construction. They are of great importance, where other materials with hydraulic properties serve as the main binding material (impure lime, hydraulic lime etc.).

One of the first rules of restoration is that historic and repair mortars must be compatible, where compatibility is broadly defined as the capacity of the repair mortar to interact with the original historic material without causing any damage, directly or indirectly. An old recipe or an exact copy of old mortar is no guarantee for compatibility, because the repair mortar must be adapted to the historic material in its present aged condition [9].

The main difference in the mineralogical composition of historical Roman cement and synthesized mixtures after firing is notable in the content of free lime - there is more of it in the synthesized mixtures.

Higher amount of cement minerals is reached in composition U2, which contains Quaternary clay (Fig. 6). It has also been observed in previous experiments [7]. There is insignificant difference in the crystallization intensity of cement minerals between the samples with various clay content (A1 - 13\%, A2 - 24\% and A3 - 30\%).

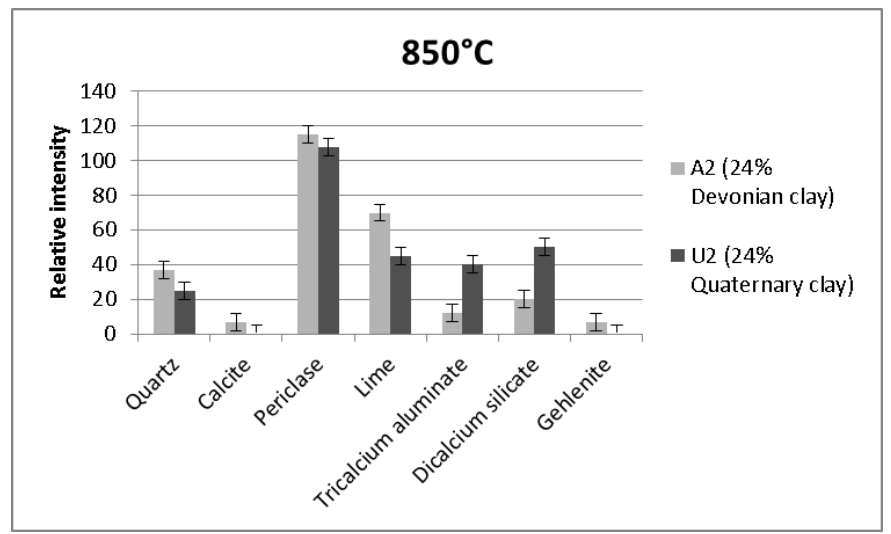

Fig. 6. Comparison of relative intensity of crystalline phases in compositions A2 and U2 after firing at $850^{\circ} \mathrm{C}$

When water is added to the synthesized composition after firing, rapid formation of calcium aluminate hydrates occurs. Hydration is completed in a few hours. The calcium aluminate hydrate is mainly detected to be $4 \mathrm{CaO} \cdot \mathrm{Al}_{2} \mathrm{O}_{3} \cdot 13 \mathrm{H}_{2} \mathrm{O}$ (Fig. 7). In the specimens fired above $800^{\circ} \mathrm{C}$ after 28 days of hydration, the XRD analysis shows that more $4 \mathrm{CaO} \cdot \mathrm{Al}_{2} \mathrm{O}_{3} \cdot 13 \mathrm{H}_{2} \mathrm{O}$ is formed in the samples fired at higher temperatures (beginning with $900{ }^{\circ} \mathrm{C}$ ). Rapid formation of this phase provides quick setting.

Hydration of dicalcium silicate is slow. Even after 28 days of hydraulic hardening there is still a significant amount of unhydrated mineral in the specimens.

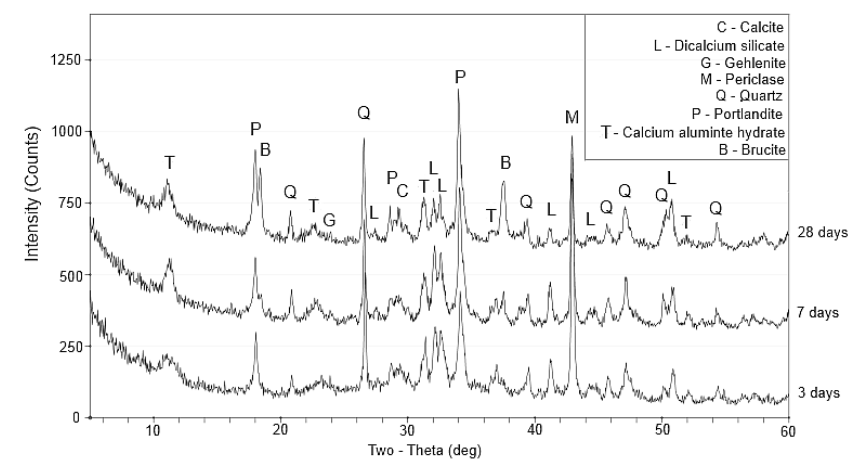

Fig. 7. XRD of composition U2 after firing at $950{ }^{\circ} \mathrm{C}$ and hydraulic hardening for 3, 7 and 28 days 
TABLE 1

Chemical Composition of DifFerent Roman CEMENT SAMPLES

\begin{tabular}{|c|c|c|c|c|c|}
\hline Component Sample & $\begin{array}{l}\text { Historical dolomitic } \\
\text { Roman cement } \\
\text { (Podolska, 1849 [6]) }\end{array}$ & $\begin{array}{c}\text { Synthesized } \\
\text { composition U2 fired } \\
\text { at } 850^{\circ} \mathrm{C} \text { (dolomite } \\
\text { with } 24 \% \text { of } \\
\text { Quaternary clay) }\end{array}$ & $\begin{array}{c}\text { Synthesized } \\
\text { composition A2 fired } \\
\text { at } 850^{\circ} \mathrm{C} \text { (dolomite } \\
\text { with } 24 \% \text { of } \\
\text { Devonian clay) }\end{array}$ & $\begin{array}{c}\text { Calcitic Roman } \\
\text { cement (the ROCEM } \\
\text { project, Cracow, 2006) }\end{array}$ & Error \pm absolute $\%$ \\
\hline $\begin{array}{l}\text { Loss of ignition at } \\
400^{\circ} \mathrm{C}\end{array}$ & & 0.40 & 2.16 & 2.02 & 0.3 \\
\hline $\begin{array}{l}\text { Loss of ignition at } \\
1000^{\circ} \mathrm{C}\end{array}$ & 22.45 & 0.73 & 2.44 & 21.47 & 0.3 \\
\hline Insoluble residue & - & 17.30 & 28.10 & 13.63 & \\
\hline Soluble $\mathrm{SiO}_{2}$ & 9.09 & 10.45 & 9.66 & 9.55 & 0.5 \\
\hline $\mathrm{CaO}$ & 40.56 & 39.70 & 28.94 & 42.33 & 0.5 \\
\hline $\mathrm{MgO}$ & 21.85 & 24.52 & 17.75 & 1.90 & 0.5 \\
\hline $\mathrm{Al}_{2} \mathrm{O}_{3}$ & 4.14 & 5.00 & 6.80 & 6.38 & 0.5 \\
\hline $\mathrm{Fe}_{2} \mathrm{O}_{3}$ & 1.32 & 1.03 & 2.04 & 0.71 & 0.2 \\
\hline $\mathrm{Na}_{2} \mathrm{O}$ & - & 0.04 & 0.05 & 0.33 & 0.02 \\
\hline $\mathrm{K}_{2} \mathrm{O}$ & - & 0.32 & 2.55 & 1.65 & 0.02 \\
\hline $\mathrm{CaO} / \mathrm{MgO}$ & 1.9 & 1.6 & 1.6 & 22.3 & - \\
\hline
\end{tabular}

Chemical composition of both synthesized binders is close to historically produced dolomitic Roman cement (Table 1) as it has been expected after calculations based on the chemical composition of raw materials. Particularly important is the content of active (soluble) $\mathrm{SiO}_{2}, \mathrm{Al}_{2} \mathrm{O}_{3}$ and $\mathrm{Fe}_{2} \mathrm{O}_{3}$. They are basic components that form cement minerals in reaction with free lime. The same content of these components is in the calcitic Roman cement, which was synthesized in the ROCEM project (2006). Basic difference between chemical composition of calcitic and dolomitic Roman cement is the $\mathrm{CaO} / \mathrm{MgO}$ ratio.

\section{CONCLUSIONS}

Low-temperature natural cement - Roman cement - was a hydraulic binder produced by firing marl below its sintering temperature and by fine grinding.

Dolomitic Roman cement was characteristic of Latvia in contrast to the rest of Europe, where calcitic Roman cement was used for the construction of buildings in the late $19^{\text {th }} /$ early $20^{\text {th }}$ century.

Nowadays, there is the necessity for compatible material for restoration needs.

The binder compatible to historical dolomitic Roman cement has been obtained from dolomite-clay mixtures containing Quaternary as well as Devonian clay.

The main crystalline phases of the binder are quartz $\left(\mathrm{SiO}_{2}\right)$, calcium oxide $(\mathrm{CaO})$, dicalcium silicate $\left(2 \mathrm{CaO} \cdot \mathrm{SiO}_{2}\right)$, magnesium oxide $(\mathrm{MgO})$ and tricalcium aluminate $\left(3 \mathrm{CaO} \cdot \mathrm{Al}_{2} \mathrm{O}_{3}\right)$.

It has been detected by the XRD analysis that crystallization of cement minerals - dicalcium silicate and tricalcium aluminate - in composition A2 appears in lower temperature $\left(750{ }^{\circ} \mathrm{C}\right)$ than in composition U2 $\left(800{ }^{\circ} \mathrm{C}\right)$. Their content increases with temperature.
Temperatures higher than $900{ }^{\circ} \mathrm{C}$ are inappropriate for the synthesis of dolomitic Roman cement because of the formation of inactive $\mathrm{MgO}$ (periclase), which hydrates slowly and can cause damage in the material.

Temperatures in the range of $800-850{ }^{\circ} \mathrm{C}$ have been chosen as optimal for the synthesis of hydraulic binder from the mixture of clay and dolomite similar to natural dolomitic Roman cement.

\section{ACKNOWLEDGEMENTS}

The research has been carried out in the framework of the ERDF Project "Elaboration of Innovative Low Temperature Composite Materials from Local Mineral Raw Materials" (No. 2010/0244/2DP/2.1.1.1.0/10/APIA/VIAA/152).

\section{REFERENCES}

1. Kozlowski, R., Adamski, G., Mucha, D. Roman Cements - Key Materials in Effectively Restoring the Built Heritage of the $19^{\text {th }}$ Century/ Early $20^{\text {th }}$ Century. In: Scientific Journal of Riga Technical University, Material Science and Applied Chemistry, Riga, Latvia, 2004, vol. 8, p. 102-109.

2. Grosvalds, I., Lagzdina, S., Sedmalis, U. Dolomitic Romancement Low Temperature Hydraulic Binder. In: Abstracts of $10^{\text {th }}$ International Congress on the Chemistry of Cement, Gothenburg, Sweden, 1997, vol. 2, p. $52-55$.

3. Home page of the ROCEM project. www.heritagescience.pl

4. Lagzdina, S., Bidermanis, L., Sedmalis, U. New Material in the System Clay - Dolomite. Scientific Israel - Technological Advantages, 2003, vol. 1-2, p. 113-118.

5. Sedmalis, U. Widespread Mineral Raw Materials of Latvia and Possibilities of Their Application. Latvian Journal of Chemistry, 1997, vol. 2, p. 16-30.

6. Eiduks, J., Grosvalds, I. Development of the Production of Dolomitic Romancement in Russia and in the Territory of Latvia. (in Russian) In: Latvijas valsts P.Stučkas universitātes zinātniskie raksti, XXII sēj., Ķīmijas fakultāte, VI, 1958, 283-295.

7. Barbane, I., Sedmale, G., Dzene, L. Research of Dolomite-Clay Mixtures for Development of Roman Cement. In: Scientific Journal of Riga Technical University, Material Science and Applied Chemistry, Riga, Latvia, 2011, vol. 24, p. 35-38. 
8. Svinka, V., Bidermanis, L., Svinka, R., Lindina, L., Cimmers, A., Timma, I. Thermochemical Reactions of Clay Minerals for Production of Honeycomb Ceramics. In: Scientific Journal of Riga Technical University, Material Science and Applied Chemistry, Riga, Latvia, 2011, vol. 24, p. 56-60.

9. Klisinska-Kopacz, A., Tislova R., Adamski G., Kozlowski R. Pore Structure of Historic and Repair Roman Cement Mortars to Establish Their Compatibility. Journal of Cultural Heritage, 2010, vol. 11, p. 404410. http://dx.doi.org/10.1016/j.culher.2010.03.002

10. Hughes, D.C., Jaglin, D., Kozlowski, R., Mucha, D. Roman Cements - Belite Cements Calcined at Low Temperature. Cement and Concrete

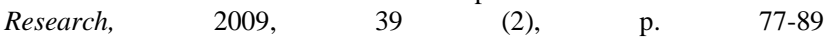
http://dx.doi.org/10.1016/j.cemconres.2008.11.010

11. LVS EN 196-2:2005. Test Methods of Cement.

12. Teutonico, J.M. A Laboratory Manual for Architectural Conservators. ICCROM, Rome, 1988, p. 35-52.

Inta Barbane - B.sc.ing. (2011), second-year Master's degree student at Riga Technical University (RTU), Faculty of Materials Science and Applied Chemistry, study programme "Chemical Technology".

For five years I.Barbane has been working as a Research Assistant at the Laboratory of Chemical Analyses of Silicate Materials, Faculty of Materials Science and Applied Chemistry of RTU. The main direction of work is dedicated to chemical analyses of historic mortars, restoration of stone materials and synthesis of new binders for restoration needs.
Address: Azenes Str. 14/24, Riga, LV-1048, Latvia

E-mail: inta.barbane@rtu.lv

Inta Vitina - Dr.sc.ing. (1992), Leading Researcher. The main directions of research activities - examination of stone materials of Latvian monuments, analysis of stone corrosion, supervision of restoration activities. I.Vitina is the author of more than 130 scientific publications in scientific periodicals. Institute of Silicate Materials, Riga Technical University

Address: Azenes Str. 14/24, Riga, LV-1048, Latvia

E-mail: vitina@ktf.rtu.lv

Linda Krage - Dr.sc.ing. (1999), Associate Professor/ Leading Researcher. Scientific interests - artificial and natural binders for building materials, concrete, lime, as well as the restoration of historical buildings - historical natural stone investigation, chemical analysis, assessment of deterioration. L.Krage is the author of more than 40 scientific publications in scientific periodicals.

Institute of Silicate Materials, Riga Technical University

Address: Azenes Str. 14/24, Riga, LV-1048, Latvia

E-mail: linda@ktf.rtu.lv

\section{Inta Barbane, Inta Vītiṇa, Linda Krāge. Zemtemperatūras hidrauliskās saistvielas restaurācijas vajadzībām}

Vienlaikus ar historisma un jūgendstila uzplaukumu Eiropas arhitektūrā 19. un 20. gs. mijā būvniecībā dominēja zemas temperatūras hidrauliskas saistvielas, tajā skaitā romāncements. Tā ir dabīga saistviela, kas iegūta, apdedzinot merğeli - karbonātu iezi ar augstu mālu saturu - temperaturās, kas zemākas par tā saķepšanas temperatūru $\left(800-1200^{\circ} \mathrm{C}\right)$. Atšķirīibā no Centrāāās Eiropas, kur ticis lietots kalı̧ķakmens merğelis, Latvijas teritorijā no 1865. gada līdz II Pasaules karam ražoja dolomītromāncementu, par izejvielu izmantojot vietējo dolomīta merğeli. Mūsdienās vēsturiskais materiāls vairs netiek ražots un ziņas par tā īpašībām un ieguvi ir zudušas. Tomēr restaurācijas vajadzībām nepieciešams izzināt šīs saistvielas īpašības un iegūt ar to saderīgu materiālu. Tādēḷ tiek veikts pētījums, lai sintezētu saistvielu no vietējā māla un dolomīta, kas būtu saderīga ar vēsturisko dolomītromāncementu. Šim mērķim sausā veidā tika sajaukts pulverveida dolomīts ar divu tipu māliem - kvartāra un devona, presēti plākšnveida paraugi un apdedzināti $750-950^{\circ} \mathrm{C}$ temperatūrā. Mālu saturs paraugos (13-30 \%) ir pietuvināts tā saturam vēsturiski lietotajā dolomīta merǵelī. Pēc apdedzināšanas ar rentgena difraktometrijas fāžu analīzes metodi noskaidrots, ka neatkarīgi no mālu tipa, to maisîjumā ar dolomītu iespējams iegūt saistvielu, kas fāžu un k̦īmiskā sastāva ziņā ir tuva vēsturiskajām saistvielām un ir perspektīva pielietojumam restaurācijā. Galvenās kristāliskās fāzes iegūtajā materiālā ir tādas pašas kā apdedzinātā dolomīta merǵelī, proti, kvarcs $\left(\mathrm{SiO}_{2}\right)$, kalcija oksīds $(\mathrm{CaO})$, dikalcija silikāts $\left(2 \mathrm{CaO} \cdot \mathrm{SiO}_{2}\right)$, magnija oksīds $(\mathrm{MgO})$, trikalcija alumināts $\left(3 \mathrm{CaO} \cdot \mathrm{Al}_{2} \mathrm{O}_{3}\right)$ un gelenīts $\left(2 \mathrm{CaO} \cdot \mathrm{Al}_{2} \mathrm{O}_{3} \cdot \mathrm{SiO}_{2}\right)$. Cementa minerālu veidošanās konstatēta temperatūrās, kas augstākas par $800^{\circ} \mathrm{C}$.

\section{Инта Барбане, Инта Витиня, Линда Краге. Низкотемпературные гидравлические вяжущие материалы для реставрации}

Одновременно с процветанием югенстиля в Европейской архитектуре накануне XIX и XX века в строительстве доминировали вяжущие материалы, полученные при низких температурах, в том числе романцемент. Это натуральное вяжущее вещество, которое получено обжигом мергеля (карбонатная порода, содержащая высокий уровень глины) в температурах, ниже спекания (800-1200 $\left.{ }^{\circ} \mathrm{C}\right)$. В Центральной Европе использовался известковый мергель, однако, в Латвии с 1865 г. до II Мировой Войны производили доломитный романцемент, для которого в качестве сырья использовался местный доломитовый мергель. В наши дни исторический материал больше не производится, так как отсутствует сырье и знания о нем потеряны. Поэтому целью данной работы является изучение синтеза доломитового романцемента, используя в качестве сырья местный "доломит" и глину, и получение материала с соотвующими физико-химическими свойствами историческому романцементу. Для этой цели в сухом виде смешаны порошкообразный доломит с двумя типами глины - четвертичной или девонской. Методом прессования получены плиткообразные образцы, которые обжигались при температуре 750-950 ${ }^{\circ} \mathrm{C}$. Содержание глины в образцах (13-30 \%) близко к историческому доломитовому мергелю. После обжига, методом рентгенновского фазового анализа, выяснено, что независимо от типа глины в смеси с доломитом возможно получить вяжущее вещество, которое по фазовому и химическому составу соответствует историческому романцементу, следовательно, перспективному для реставрации. Главные кристаллические фазы в полученным материале такии же как в обжженным мергеле - кварц $\left(\mathrm{SiO}_{2}\right)$, иксид кальция $(\mathrm{CaO})$, силикад дикальция $\left(2 \mathrm{CaO} \cdot \mathrm{SiO}_{2}\right)$, оксид магния $(\mathrm{MgO})$, трикальция алуминат $\left(3 \mathrm{CaO} \cdot \mathrm{Al}_{2} \mathrm{O}_{3}\right)$ и геленьит $\left(2 \mathrm{CaO} \cdot \mathrm{Al}_{2} \mathrm{O}_{3} \cdot \mathrm{SiO}_{2}\right)$. Минералы цемента обноружены при температурах свыше $800^{\circ} \mathrm{C}$. 